Murashige, T. and F. Skoog (1962): A revised medium for rapid growth and bioassays with tobacco tissue cultures. Physiol Plantarum 15(3): 473-497.

OGAWA, T., H. FuKUOKA and Y. OHKAWA (1994): Induction of cell division of isolated pollen grains by sugar starvation in rice. Breed Sci 44: 75-77.

Pintos, B. J. A. MAnzanera and M. A. Bueno (2005): Cytological analysis of early microspore divisions leading to gametic embryo formation in Quercus suber L. anther cultures. Acta Physiologiae Plantarum 27(4B): 703-708.

Pintos, B. (2007a): Antimitotic agents increase the production of doubled-haploid embryos from cork-oak anther culture. Journal of Plant Physiology 164(12): 1595-1604. doi:10.1016/j.jplph.2006.11.012.

Pintos, B., J. A. Manzanera and M. A. Bueno (2007b): Protocol for Doubled Haploid micropropagation in Quercus suber L and Marker-assisted verification, pp 163-178 in Protocols for Micropropagation of Woody trees and Fruits edited by S. M. JAIN and H. HÄGGMAN. Springer Dordrecht. The Netherlands.

Pintos, B., M. A. Bueno, B. Cuenca and J. A. Manzanera (2008): Synthetic seed production from encapsulated somatic embryos of cork oak (Quercus suber L.) and automated growth monitoring. Plant Cell, Tissue and Organ Culture 95(2): 217-225. DOI: 10.1007/s11240008-9435-4.

Pintos, B., J. A. Manzanera and M. A. Bueno (2010): Oak somatic and gametic embryos maturation is affected by charcoal and specific aminoacids mixture. Ann. For Sci 67205 p 9 doi: 10.1051/forest/2009098.
PRAKASH, J. and K. L. GILES (1987): Induction and growth of androgenic haploids. Int Rev Cytol 107: 273-292.

Rodriguez-Serrano, M., I. Barany, D. Prem, M. J. Coronado, M. C. Risueno and P. S. Testillano (2012): NO, ROS, and cell death associated with caspaselike activity increase in stress-induced microspore embryogenesis of barley. Journal of Experimental Botany 63(5): 2007-2024. DOI: 10.1093/jxb/err400.

Sghaier-Hammami, B., L. Valledor, N. DriRa and J.V. JORRIN Novo (2009): Proteomic analysis of the development and germination of date palm (Phoenix dactylifera L) zygotic embryos. Proteomics 9: 2543-2554.

Shariatpanahi, M. E., K. Belogradova, L. Hessamvaziri, E. HeBerle-Bors and A. TOURAev (2006): Efficient embryogenesis and regeneration in freshly isolated and cultured wheat (Triticum aestivum L.) microspores without stress pre-treatment. Plant Cell Rep 25: 1294-1299.

Sommer, H. E., C. L. Brown and P. P. KormaniK (1975): Differentiation of plantlets in longleaf pine (Pinus palustris Mill.) tissue cultured in vitro. Bot Gaz 136: $196-200$.

Steinkellner, H., C. LeXer, E. TURETSCheK and J. GlÖssl (1997): Conservation of (GA)n microsatellite loci between Quercus species. Mol Ecol 6: 1189-1194.

\title{
Genetic variation and genetic gain in growth traits, stem-branch characteristics and wood properties and their relationships to Eucalyptus urophylla clones*)
}

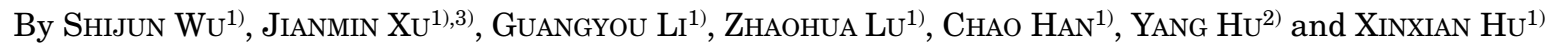

(Received $17^{\text {th }}$ January 2013)

\begin{abstract}
Growth traits, wood properties, stem-branch characteristics and bark percentage were assessed for $60 \mathrm{Euca}$ lyptus urophylla S.T. Blake clones in southern China measured at age 21, 52, 71 and 96 months. Analysis of

\footnotetext{
1) Research Institute of Tropical Forestry, Chinese Academy of Forestry, Guangdong Guangzhou 510520, China.

$\left.{ }^{2}\right)$ Xinhui Research Institute of Forestry Science, Guangdong Jiangmen 529100, China

3) Corresponding Author: JIANMIN Xu. E-Mail: jianmxu@163.com

*) This study was undertaken as a project for the National Twelfth Five-Year Science and Technology Plan "Breeding of High yield and High Resistance New Species of Eucalyptus" (2012BAD01B0401). First Author: ShIJUN Wu, Ph.D. Research Institute of Tropical Forestry, Chinese Academy of Forestry. E-Mail: wushijun0128@163.com
}

variance showed that there were significant differences on growth traits, wood properties and individual tree wood weight among clones. Coefficients of genotypic variation ranged from $12.12 \%$ to $53.16 \%$ for growth traits, $9.02 \%$ to $20.18 \%$ for wood properties, $21.75 \%$ to $22.71 \%$ for stem-branch characteristics, $28.31 \%$ for bark percentage and $51.20 \%$ for individual tree wood weight. Repeatability ranged from 0.36 to 0.53 for growth traits, 0.35 to 0.51 for wood properties, 0.21 to 0.24 for stembranch characteristics, 0.07 for bark percentage and 0.31 for individual tree wood weight. The strongly negative genotypic correlations suggesting that selection on growth traits at 21 months can not be effective to predict growth traits at 96 months whereas it could be used to predict growth traits at 52 and 71 months. The genotypic correlations between growth traits and basic density were ranged from -0.78 to 0.28 and weakly positive phenotypic correlations were found between growth 
traits and basic density, ranging from 0.03 to 0.09 . The selection gain on diameter at breast height over bark by different selection proportions at 21, 52, 71 and 96 months old expressed that selection gain at 71 months was some what higher than that at other ages during $10 \%$ to $30 \%$ selection proportion, while selection gain at 52 months was some what higher than that at other ages during $60 \%$ to $90 \%$ selection proportion. Wood properties and individual tree wood weight which are strongly related to end production and economically important in pulp production should be studied extensively especially for pulp breeding.

Key words: multiple traits; nondestructive evaluation; individual tree wood weight; repeatability; age trend; simple weighting coefficient method.

\section{Introduction}

With the steady increase in global population and the reduction of native forest and the protection of natural forests by governments, particularly in developing countries, tree plantations and agroforestry have become the basic source to meet the increasing demand for pulp and paper and wood products (XU and DeLL, 2002; HUANG and Dell, 2002; DANusevicius and LindGren, 2002; BuLL et al., 2006; KIEN et al., 2009). Forest trees, unlike livestock or crops, are typified by long rotations and long breeding cycles and the expression of genes in relation to age and relationships with environment also need to be considered in tree genetics and tree breeding (KusNANDAR et al., 1998; BORRALHO, 2002; BOUVET et al., 2003). As an important type of forestry, commercial forest plantations have become a competitive alternative to harvesting natural forests in many parts of the world, especially in the tropical and sub-tropics (HENRI, 2001). The launching of large-scale commercial plantation programs and a significant increase in the area of plantations were in 1960s and 2000s (BuLl et al., 2006). However, short-rotation plantation management which have rotation often less than 10 years has been becoming a more and more important forest practice in many countries, particularly those lacking land or forest resources and with pressures from increasing populations and demands on forest products, for various uses such as energy, construction material production, pulp wood and other purposes (WEI and BorRALHO, 1996; FANG et al., 1999; WEI, 2002; LEMENIH and BEKELE, 2004).

Among the genera selected for plantations, Eucalyptus has many characteristics that make it more suitable for short-rotation plantation and become most widely used general commercial plantation in Australia (FORRESTER et al., 2006), Asia (GAN et al., 2004; KIEN et al., 2010; WU et al., 2011b), South America (BERNARDO et al., 1998; LEITE et al., 2002) and South Africa (RETIEF and STANGER 2009) when compared to other species, such as fast-growing, well adaptability, short-rotation, excellent wood properties, vigorous hybrids and large natural genetic populations occur (XU and DELL, 2002; HUANG and Dell, 2002; DANUSEvicius and LindGREN, 2002; KIEN et al., 2009; WARREN et al., 2009). Compared with other Eucalyptus species growing throughout China, Eucalyptus urophylla S.T. Blake is very important plantation in tropical and subtropical area (CHEN et al.,
2006; HE et al., 2011). E. urophylla is native to seven islands of the Sumba archipelago in eastern Indonesia, in a latitudinal range from $7^{\circ} 30^{\prime} \mathrm{S}$ to $10^{\circ} \mathrm{S}$ and altitudinal range from 90 to $3000 \mathrm{~m}$ (WRIGHT and OsORIO, 1996; XU et al., 2001; QI, 2002; KIEN et al., 2009). It was introduced into Southern China in 1980s under the Australia-China Program of Technical Cooperation (MCKENNEY, 1998). In China, superior clones for cellulose production have been abstained mainly through inter-specific hybridization between $E$. urophylla and other species, via natural or controlled pollination, owing to the good performance for wood volume of same species in hybrid combinations (HARDY et al., 2002; BUEREN, 2004; Luo et al., 2010). However, they grow poor in the tropical climate with mean annual rainfall of less than $1000 \mathrm{~mm}$ and a long hot dry season of more than six months (VARGHESE et al., 2008).

Clonal forestry, in a strict sense, refers to use a number of tested, selected and identified clones in plantation forestry for estimating basic genetic parameters in order to determine the best strategies for clonal testing and breeding, and to predict genetic gains from deploying the best clones (OsORIo et al., 2001; Osorio et al., 2003; HAI et al., 2008b; Li et al., 2011). Indeed, widely used eucalypt cultivation in China is based on a small number of clones (PEGG et al., 2006; Li et al., 2011), and overwhelming majority of them are established with germplasm derived wholly from $E$. grandis W. Hill ex maiden, E. urophylla or from hybrids of these two species (HARDY et al., 2002; BUEREN, 2004; LUO et al., 2010). These large areas of monoclonal or oligoclonal plantations of restricted genetic diversity carry potential risks both ecological and genetically (ARAVANOPOULOS et al., 1999; WANG et al., 1999; FORRESTER et al., 2006; PliURA et al., 2007).

Through more than 30 years of testing and domestication, there has been remarkable progress in terms of wood volume in China. However, the mean annual increment in volume of eucalypt plantations in China is nearly the mean annual yield of eucalypt plantations in the world. In some tropical and subtropical regions, the mean annual yield of eucalypt plantations is more than $20 \mathrm{~m}^{3} \mathrm{ha}^{-1}$ year ${ }^{-1}$, and some commercial plantations in countries such as Brazil, South Africa, Congo and Australia can be as much as $30-90 \mathrm{~m}^{3} \mathrm{ha}^{-1}$ year ${ }^{-1}$ (Mo et al., 2002; ToIT et al., 2010). More over, productivity of eucalypt plantations is very variable from 2 to $70 \mathrm{~m}^{3} \mathrm{ha}^{-1}$ year ${ }^{-1}$, which suggesting a great potential for improving productivity of eucalypt plantations in southern China (YANG, 2003; XU et al., 2003a). Consequently, selecting new clones and increasing the productivity of existing plantations to supply the growing consumption of wood and offer the largest potential for reducing the unit cost of wood production are extremely urgent in China.

Improvement of growth, stem straightness and resistance has been the primary focus of eucalypts breeding owing to their economic importance and ease of measurement. Numerous studies have been conducted in an attempt to understand genetic parameters and breeding value in growth traits, stem characteristics and resistance for E. urophylla families and provenances at early 
ages (HUANG et al., 1999; LeITE et al., 2002; LIANG and BAI, 2003; LU et al., 2003, 2004; XU et al., 2003b, 2005; LU et al., 2004, 2010; Li et al., 2005a, 2005b; QUANG et al., 2009; KIEN et al., 2009). Currently, the information on genetic parameters, genetic gain and correlations between multiple-traits of $E$. urophylla clones with age trends are limited in China.

The objectives of this study were to: (1) compare growth traits, stem characteristics and wood properties of different clones, (2) estimate repeatability of traits with age trends, (3) look at the genotypic and phenotypic relationships between growth traits, stem characteristics and wood properties, (4) evaluate genetic gain for different purposes, and (5) explore the implications for tree improvement. This information will be used to develop appropriate selection strategies for eucalypt breeding programs in southern China.

\section{Material and Methods}

\section{Trial description}

The trial was established at Duhui village of Jiangmen City in Guangdong $\left(22^{\circ} 33^{\prime} \mathrm{N}, 113^{\circ} 02^{\prime} \mathrm{E}, 45 \mathrm{~m}\right.$ asl), and is affected by the south subtropical monsoon with annual mean temperature of $22.3^{\circ} \mathrm{C}$ and annual mean rainfall of $1750 \mathrm{~mm}$. Mean January temperature at this location is $6.7^{\circ} \mathrm{C}$, mean for July $28.3^{\circ} \mathrm{C}$ and the minimum temperature was $2.9^{\circ} \mathrm{C}$. There is not frost period and average annual mean accumulated temperature is $7653^{\circ} \mathrm{C}$. The red lateritic earth was derived from sandstone. The dominant plants in the undergrowth of the original tree canopy included Dicranopteris pedata (Honutt.) Nakaike, Mussaenda pubeseens Ait and Rhodomyrtus tomentosa Hassk. Planting pits $(60 \mathrm{~cm} \times$ $50 \mathrm{~cm} \times 40 \mathrm{~cm}$ ) were prepared and 0.75 kilogram eucalypts fertilizer (N: $\mathrm{P}: \mathrm{K}=8: 15: 8)$ was applied in first years for individual tree. The details of assessed clones are presented in Table 1. Sixty clones were planted in April 2003 and most of them were selected and propagated from a provenance / family trials established in 1995. Clone 10, 21, 22, 25 and 36 were superior phenotypes selected from other family tests. The seed lot of clone 40, 46 and 54 were mixed included 14531, 14532, 12895 and 12987.The field design was a randomized complete block with 20 replications and one-tree line plots planted with a spacing of $3.0 \mathrm{~m} \times 2.0 \mathrm{~m}$.

Table 1. - Provenances details of the clones assessed.

\begin{tabular}{|c|c|c|c|c|c|}
\hline Clones No. & Seed lot & Locations & $\begin{array}{l}\text { Latitude } \\
\qquad(\mathrm{S})\end{array}$ & $\begin{array}{l}\text { Longitude } \\
\text { (E) }\end{array}$ & $\begin{array}{l}\text { Altitude } \\
(\mathrm{m})\end{array}$ \\
\hline 15 & 12897 & Mt. Mandiri, IND & $8^{\circ} 33^{\prime}$ & $122^{\circ} 35^{\prime}$ & 830 \\
\hline $6,31,53,60$ & 14531 & $\begin{array}{l}\text { Mt. Egon, Flores, } \\
\text { IND }\end{array}$ & $8^{\circ} 38^{\prime}$ & $122^{\circ} 27^{\prime}$ & 515 \\
\hline $5,16,35,43,45,51$ & 14532 & $\begin{array}{l}\text { Mt. Lewotobi, Flores, } \\
\text { IND }\end{array}$ & $8^{\circ} 31^{\prime}$ & $122^{\circ} 45^{\prime}$ & 398 \\
\hline 11 & 14533 & Flores Island, IND & $8^{\circ} 31^{\prime}$ & $122^{\circ} 45^{\prime}$ & 398 \\
\hline $\begin{array}{c}1,3,4,9,27 \\
28,41,47,57,59\end{array}$ & 14534 & $\begin{array}{l}\text { Mt. Egon, Flores, } \\
\text { IND }\end{array}$ & $8^{\circ} 38^{\prime}$ & $122^{\circ} 27^{\prime}$ & 340 \\
\hline $\begin{array}{c}2,8,12,13,18,20,24,32 \\
33,34,52\end{array}$ & 17565 & $\begin{array}{l}\text { Lewotobi, Flores } \\
\text { Island, IND }\end{array}$ & $8^{\circ} 32^{\prime}$ & $122^{\circ} 48^{\prime}$ & 375 \\
\hline 26,48 & 17566 & Wukoh, Flores, IND & $8^{\circ} 35^{\prime}$ & $122^{\circ} 35^{\prime}$ & 600 \\
\hline $\begin{array}{c}23,30,37,39,42 \\
44,49,55,56\end{array}$ & 17567 & Egon, Flores, IND & $8^{\circ} 38^{\prime}$ & $122^{\circ} 27^{\prime}$ & 450 \\
\hline 29 & 17571 & $\begin{array}{l}\text { Mt. Egon, Flores, } \\
\text { IND }\end{array}$ & $8^{\circ} 38^{\prime}$ & $122^{\circ} 27^{\prime}$ & 525 \\
\hline $19,38,50$ & 17572 & $\begin{array}{l}\text { Mt. Egon, Flores, } \\
\text { IND }\end{array}$ & $8^{\circ} 37^{\prime}$ & $122^{\circ} 27^{\prime}$ & 600 \\
\hline 14,17 & 17574 & $\begin{array}{l}\text { Mt. Egon, Flores } \\
\text { Island, IND }\end{array}$ & $8^{\circ} 36^{\prime}$ & $122^{\circ} 28^{\prime}$ & 550 \\
\hline 7,58 & B2 & Brazil & & & \\
\hline $10,21,22,25,36$ & Mixed & \multicolumn{4}{|c|}{ Mixed Provenances include $14531,14532,12895$ and 12987.} \\
\hline $40,46,54$ & Other & \multicolumn{4}{|c|}{ Selected From Other Family Trials } \\
\hline
\end{tabular}




\section{Data collection}

Measurements of diameter at breast height over bark (DBHOB in $\mathrm{cm}$ ) and height (HGT in $\mathrm{m}$ ) were collected in January 2006, August 2008, March 2010 and April 2011, at which time the trials were aged 21, 52, 71 and 96 months. Individual tree volume over bark (VOL in $\mathrm{m}^{3}$ ) was calculated using the following formula as described by MCKenNeY et al. (1991):

$$
\mathrm{VOL}=\mathrm{HGT} \times \mathrm{DBHOB}^{2} / 30000
$$

Bark percentage (Bark Perc) for each individual tree was defined as the ratio of the area of bark at breast height $(1.3 \mathrm{~m})$ to total cross-sectional area at the same height (Wu et al., 2011b).

$$
\text { Bark Perc }(\%)=\frac{\mathrm{DBHOB}^{2}-(\mathrm{DBHOB}-2 \mathrm{BT})^{2}}{\mathrm{DBHOB}^{2}} \times 100 \% \text {, }
$$

where BT (cm) is the average bark thickness. Bark thickness was measured using a caliper for former ten replications trees in April 2011.

The equation of wood volume under bark (VOLU) is the product of diameter at breast under bark (DBHUB) and height.

$$
\mathrm{VOLU}=\mathrm{HGT} \times \mathrm{DBHUB}^{2} / 30000
$$

And the individual tree wood weight (WW, in $\mathrm{kg}$ ) also can be recognized as the product of VOLU and basic density (BD).

$$
\mathrm{WW}=\mathrm{VOLU} \times \mathrm{BD} \times 1000
$$

BD was determined by a volumetric method, which required measuring weight of water displaced by immersion and oven dry weight of core in the laboratory (Miranda et al., 2001; ISIK and Li, 2003; PELletier et al., 2008; Wu et al., 2010, 2011a). Five millimeter thick increment cores, passed from bark to bark through the pith, were obtained at breast height $(1.3 \mathrm{~m})$ from the same trees that were measured with caliper for bark thickness in April 2011. Cores were removed in the north-south orientation as this corresponded to the direction of the planted rows. The increment cores were immediately stored in plastic tubes with both ends sealed (KIEN et al., 2008).

Modulus of elasticity (MOE) often considered as an important indicator of wood quality was used to be calculated by green density of cores and stress wave velocity (SWV) by Fakopp microsecond timer (WANG et al., 2000; KNOWLES et al., 2004; Wu et al., 2011a; Wu et al., 2011b).

$$
\mathrm{MOE}=\rho \omega^{2}
$$

where $\rho$ is the green wood density of the stem in $\mathrm{g} \cdot \mathrm{cm}^{-3}$, $\omega$ is the SWV in $\mathrm{m} \cdot \mathrm{s}^{-1}$.

SWV was determined from sample length $(\mathrm{L}=1500$ $\mathrm{mm}$ ) and transit time (t) as (DICKSON et al., 2003; RAYMOND et al., 2004; WAGHORN et al., 2007; MATHESON et al., 2008; ISHIGURI et al., 2008):

$$
\mathrm{SWV}=\mathrm{L} / \mathrm{t}
$$

The transit time was measured for former ten replications trees in April 2011.
Stem straightness (STR) was assessed using a fourclass relative scoring, where class 4 is a very straight stem without knots and scars, 2-3 is straight or has a slight bend at one position with few knots and scars, 1 is a very crooked stem. Branch size (BRA) was assessed using a three-class relative scoring, where class 3 is a tree with small and uniform branch, 2 is a tree with acceptable branch, 1 is a tree with very big branches. They were graded for all trees in April 2011.

\section{Statistical analysis}

Variation among ramets of the sampled clones was analyzed by analysis of variance, using a linear model (HANSEN and ROULUND, 1996):

$$
\mathrm{y}_{\mathrm{ij}}=\mu+\alpha_{\mathrm{i}}+\beta_{\mathrm{j}}+\varepsilon_{\mathrm{ij}}
$$

where $y_{i j}$ is the performance of the ramet of $i^{\text {th }}$ clone within the $\mathrm{j}^{\text {th }}$ replicate, and $\mu$ is the general mean, $\alpha_{\mathrm{i}}$ is the random effect of the $i^{\text {th }}$ clone, $\beta_{j}$ is the random effect of the $\mathrm{j}^{\text {th }}$ replicate, $\varepsilon_{\mathrm{ij}}$ is the random error.

The repeatability of the clone mean was calculated following HAI et al. (2008a):

$$
\mathrm{R}=\sigma_{\mathrm{a}}^{2} /\left(\sigma_{\mathrm{a}}^{2}+\sigma_{\mathrm{t}}^{2}+\sigma_{\mathrm{e}}^{2}\right),
$$

where $\sigma^{2}$ is the variance of clone, $\sigma_{t}^{2}$ is the variance of replicate, $\sigma_{\mathrm{e}}^{2}$ is the residual variance.

The genotypic coefficient of variation (CV) was calculated as (PLIURA et al., 2007; HAI et al., 2008):

$$
\mathrm{CV}=\left(100 \sigma_{\mathrm{c}} / \mathrm{x}\right) \times 100 \%,
$$

where $\mathrm{x}$ is the phenotypic mean. The equation expresses a standardized measure of the genetic variance relative to the mean of trait.

The genotypic correlation $\mathrm{r}_{\mathrm{A}(\mathrm{xy})}$ of traits $\mathrm{x}$ and $\mathrm{y}$ was calculated as (PliURA et al., 2007; StACKPOLE et al., 2010):

$$
r_{A(x y)}=\frac{\sigma_{a(x y)}}{\sqrt{\sigma_{a(x)}^{2} \times \sigma_{a(y)}^{2}}}
$$

where $\sigma_{\mathrm{a}(\mathrm{x})}^{2}$ is the clone variance component for the trait $x, \sigma_{\text {a(y) }}^{2}$ is the clone variance component for the trait $y$ and $\sigma_{\mathrm{a}(\mathrm{xy})}^{2}$ is the clone covariance component.

Simple weighting coefficient equation as follows:

$$
\mathrm{I}=\frac{\mathrm{w}_{1} \mathrm{~h}_{1}^{2}\left(\mathrm{X}_{1}-\overline{\mathrm{X}}\right)}{\sigma_{1}}+\frac{\mathrm{w}_{2} \mathrm{~h}_{2}^{2}\left(\mathrm{X}_{2}-\overline{\mathrm{X}}\right)}{\sigma_{2}}+\ldots .+\frac{\mathrm{w}_{\mathrm{i}} \mathrm{h}_{\mathrm{i}}^{2}\left(\mathrm{X}_{\mathrm{i}}-\overline{\mathrm{X}}\right)}{\sigma_{\mathrm{i}}}
$$

where $\mathrm{I}$ is the selection index value, $\mathrm{w}_{\mathrm{i}}$ is the relative economic weight of $i^{\text {th }}$ trait, $h^{2}$ is the clonal repeatability of $i^{\text {th }}$ trait, $X_{i}$ is mean value of $i^{\text {th }}$ trait within clone, $\bar{X}$ is the general mean within trait and $\sigma$ is the standard deviation of $i^{\text {th }}$ trait.

The genetic gain (\%) was calculated as (XU et al., 2003a):

$$
\Delta G=R \cdot S \cdot \bar{X}^{-1}
$$

where $\mathrm{R}$ is the clonal repeatability, $\mathrm{S}$ is deviation between selected mean and general mean and $\overline{\mathrm{X}}^{-1}$ is the general mean.

The significance of fixed effects was assessed using F-tests. Meanwhile, the standard errors of genotypic 
correlations were calculated following methodologies described by PHIURA et al. (2006) and MACDONALD et al. (1997). The analysis of variance and genotypic correlation were performed using the PROC ANOVA and VARCOMP in SAS.

\section{Results and Discussion}

\section{Variance among clones and replicates}

The analysis of variance of studied traits among clones and replicates at different ages is presented in Table 2. The results showed that there were significant differences on growth traits, SWV, BD, MOE and WW among clones, indicating clear differences among clones. According to equation 4, WW was the product of VOLU and BD. And both of them among clones were significant differences at 0.01 level, whereas the WW differences among clones was only on 0.05 level. This may be due to the ubiquitous negative relationships between growth traits and BD (WEI and BORRALHO, 1997; MACDONALD et al., 1997; KIEN et al., 2008). However, the differences on stem-branch characteristics and bark percentage among clones were not significant expressing that there were not differences among clones.

Table 2. - Analysis of variance of the studied traits at 21, 52, 71 and 96 months old.

\begin{tabular}{|c|c|c|c|c|c|}
\hline \multicolumn{2}{|c|}{ Traits } & \multicolumn{2}{|c|}{ Clones } & \multicolumn{2}{|c|}{ Replicates } \\
\hline & & $\Gamma$ & $\mathrm{P}$ & $\mathrm{F}$ & $P$ \\
\hline \multirow{3}{*}{21 months old } & $\operatorname{HGT}(\mathrm{m})$ & 1.78 & 0.0005 & 9.72 & $<0.0001$ \\
\hline & $\mathrm{DBHOB}(\mathrm{cm})$ & 1.57 & 0.0058 & 2.31 & 0.0013 \\
\hline & $\operatorname{VOL}\left(\mathrm{m}^{3}\right)$ & 1.68 & 0.0017 & 4.34 & $<0.0001$ \\
\hline \multirow{3}{*}{52 months old } & $\operatorname{HGT}(\mathrm{m})$ & 1.65 & 0.0029 & 3.08 & 0.0002 \\
\hline & DBHOB(cm) & 2.13 & $<0.0001$ & 2.30 & 0.0060 \\
\hline & $\operatorname{VOL}\left(\mathrm{m}^{\frac{3}{3}}\right)$ & 2.10 & $<0.0001$ & 2.17 & 0.0101 \\
\hline \multirow{3}{*}{71 months old } & $\operatorname{HGT}(\mathrm{m})$ & 1.86 & 0.0003 & 26.18 & $<0.0001$ \\
\hline & $\mathrm{DBHOB}(\mathrm{cm})$ & 1.76 & 0.0010 & 22.25 & $<0.0001$ \\
\hline & $\operatorname{VOL}\left(\mathrm{m}^{3}\right)$ & 2.10 & 0.0003 & 1,34 & 0.2509 \\
\hline \multirow{11}{*}{96 months old } & $\operatorname{HGT}(\mathrm{m})$ & 1.67 & 0.0022 & 3.24 & $<0.0001$ \\
\hline & $\mathrm{DBHOB}(\mathrm{cm})$ & 1.60 & 0.0049 & 5.52 & $<0.0001$ \\
\hline & $\operatorname{VOL}\left(\mathrm{m}^{3}\right)$ & 1.90 & 0.0002 & 1.51 & 0.0783 \\
\hline & $\operatorname{VOLU}\left(\mathrm{m}^{3}\right)$ & 1.93 & 0.0001 & 1.15 & 0.2956 \\
\hline & STR & 1.26 & 0.1044 & 1.74 & 0.0279 \\
\hline & BRA & 1.31 & 0.0707 & 1.87 & 0.0152 \\
\hline & Bark Perc $(\%)$ & 1,08 & 0.3401 & 1.89 & 0.0572 \\
\hline & SWV $\left(\mathrm{km} \mathrm{s}^{-1}\right)$ & 1.90 & 0.0008 & 10.68 & $<0.0001$ \\
\hline & $\mathrm{BD}\left(\mathrm{g} \mathrm{cm}^{-3}\right)$ & 2.05 & 0.0002 & 2,40 & 0.0139 \\
\hline & $\operatorname{MOE}(\mathrm{GPa})$ & 1.53 & 0.0199 & 9,15 & $<0,0001$ \\
\hline & WW (kg) & 1,44 & 0.0392 & 1,32 & 0.2324 \\
\hline
\end{tabular}

HGT height; DBHOB diameter at breast height over bark; VOL volume over bark; VOLU volume under bark; STR stem straightness; BRA branch size; Bark Perc bark percentage; SWV stress wave velocity; BD wood basic density; MOE modulus of elasticity; WW individual tree wood weight; $\mathrm{F}$ the F-ratio; $\mathrm{P}$ the probability of the F-ratio. 
Furthermore, there were significant differences on HGT, DBHOB, stem-branch characteristics, SWV, BD and MOE among replicates at different ages at least in part due to the relatively uneven site conditions, whereas the differences on VOL, bark percentage and WW among replicates were not significant suggesting the less environmental effects on these traits. It was interesting to find that the replicates differences on VOL changed from significant differences at 0.01 level at 21 months old to significant differences at 0.05 level at 52 age months and no significant differences at 71 and 96 months old implying the environmental effects on VOL decreased with age trend. Further, the probability of the F-ratio among replicates reached peak at 71 months and then decreased nearly 0.05 level at 96 months though the value of VOLU was 0.30 at this time. A possible explanation may be at least in part due to the former environmental effects made by uneven site condition and the latter environmental effects made by relationships among individual trees and bark thickness.

\section{Clonal variation and repeatability}

Mean clonal value and ranges for growth traits, stembranch characteristics and wood properties at four ages are presented in Table 3. The mean DBHOB at 21, 52, 71 and 96 months were 10.46, 12.94, 14.11 and $16.94 \mathrm{~cm}$ respectively. Therefore the increments between ages were $2.48,1.17$ and $2.83 \mathrm{~cm}$ during 31,19 and 25 months. These results are somewhat bigger than published material on E. urophylla (KIEN et al., 2009) and other species in Pakistan (MAHMOOD et al., 2003), India (VARGHESE et al. 2008), Vietnam (KIEN et al., 2010), Aus-

Table 3. - Mean value, ranges, coefficient of variation and clonal repeatability of the studied traits at $21,52,71$ and 96 months old.

\begin{tabular}{|c|c|c|c|c|c|c|c|c|}
\hline \multicolumn{2}{|r|}{ Traits } & Mean & Minimum & Maximum & SD & $\mathrm{SE}$ & $\mathrm{CV} \%$ & $\mathrm{R}$ \\
\hline \multirow{2}{*}{$\begin{array}{c}21 \\
\text { months }\end{array}$} & HGT (m) & 12.01 & 5.00 & 19.50 & 1.45 & 0.05 & 12,12 & 0.44 \\
\hline & $\mathrm{DBI} 1 \mathrm{OB}(\mathrm{cm})$ & 10.46 & 4.00 & 14.90 & 1.86 & 0.07 & 17.80 & 0.36 \\
\hline old & $\operatorname{VOL}\left(\mathrm{m}^{3}\right)$ & 0.047 & 0.004 & 0.109 & 0.02 & 0.00 & 37.04 & 0.41 \\
\hline 52 & $\mathrm{HGT}(\mathrm{m})$ & 19.36 & 8.40 & 25.80 & 3.18 & 0.14 & 16.41 & 0.40 \\
\hline months & DBHOB(cm) & 12.94 & 6.60 & 20.70 & 2.39 & 0.11 & 17.21 & 0.53 \\
\hline old & $\operatorname{VOL}\left(\mathrm{m}^{3}\right)$ & 0.136 & 0.013 & 0.334 & 0.06 & 0.00 & 42.10 & 0.52 \\
\hline \multirow{2}{*}{$\begin{array}{c}71 \\
\text { months }\end{array}$} & HGT (m) & 21.95 & 10.20 & 27.20 & 4.33 & 0.18 & 27.19 & 0.46 \\
\hline & DBIIOB $(\mathrm{cm})$ & 14.11 & 6.80 & 26.00 & 3.48 & 0.16 & 24.68 & 0.43 \\
\hline old & $\operatorname{VOL}\left(\mathrm{m}^{3}\right)$ & 0.208 & 0.015 & 0.466 & 0.07 & 0.02 & 31.04 & 0.52 \\
\hline \multirow{11}{*}{$\begin{array}{c}96 \\
\text { months }\end{array}$} & $\mathrm{HGT}(\mathrm{m})$ & 22.14 & 11.00 & 29.00 & 5.71 & 0.26 & 38.17 & 0.40 \\
\hline & DBI IOB(cm) & 16.94 & 6.80 & 28.00 & 4.89 & 0.22 & 34.11 & 0.38 \\
\hline & $\operatorname{VOL}\left(\mathrm{m}^{3}\right)$ & 0.227 & 0.015 & 0.732 & 0.12 & 0.01 & 52.43 & 0.47 \\
\hline & VOLU $\left(\mathrm{m}^{3}\right)$ & 0.210 & 0.013 & 0.705 & 0.11 & 0.01 & 53.16 & 0.48 \\
\hline & STR & 1.46 & 1 & 4 & 0.26 & 0.01 & 21.75 & 0.21 \\
\hline & BRA & 1.73 & 1 & 3 & 0.29 & 0.01 & 22.71 & 0.24 \\
\hline & Bark Perc $(\%)$ & 14.70 & 1.1 & 28.11 & 0.04 & 0.00 & 28.31 & 0.07 \\
\hline & SWV $\left(\mathrm{km} \mathrm{s}^{-1}\right)$ & 402.97 & 276.33 & 573.33 & 36.21 & 2.44 & 9.29 & 0.47 \\
\hline & $\mathrm{BD}\left(\mathrm{g} \mathrm{cm}^{-3}\right)$ & 0.50 & 0.35 & 0.74 & 0.04 & 0.00 & 9.02 & 0.51 \\
\hline & MOE (GPa) & 15.83 & 7.15 & 30.96 & 3.23 & 0.21 & 20.18 & 0.35 \\
\hline & $W W(\mathrm{~kg})$ & 99.57 & 14.54 & 289.10 & 52.54 & 3.39 & 51.20 & 0.31 \\
\hline
\end{tabular}

HGT height; DBHOB diameter at breast height over bark; VOL volume over bark; VOLU volume under bark; STR stem straightness; BRA branch size; Bark Perc bark percentage; SWV stress wave velocity; BD wood basic density; MOE modulus of elasticity; WW individual tree wood weight; SD standard deviation; SE standard error; CV genotypic coefficient of variation; $R$ repeatability. 
tralia (KUBE et al., 2001) and China (WU et al., 2011b). $\mathrm{WU}$ et al. (2011b) reported that the mean DBHOB ranged from 11.98 to $12.60 \mathrm{~cm}$ for 19 commercial hybrid eucalypt clones at three sites in southern China measured at age 51 months.

The mean $\mathrm{BD}$ values were $0.50( \pm 0.00) \mathrm{g} \mathrm{cm}^{-3}$ at 96 months (Table 3), agreeing with previous studies by QUANG et al. (2009) and KIEN et al. (2008). KIEN et al. (2008) reported that wood basic density, estimated from $5 \mathrm{~mm}$ increment cores taken at breast height, averaged $510 \mathrm{~g} \mathrm{~cm}^{-3}$ for $E$. urophylla across two trials in northern Vietnam at the age of eight and nine years. Nevertheless, the present wood density values are somewhat lower than those reported for E. urophylla (WEI and BorralHo, 1997), Eucalyptus camaldulensis Dehnh. (VARGHESE et al., 2008; KIEN et al., 2010), Eucalyptus nitens Maiden (KUBE et al., 2001) and higher than Eucalyptus globulus Labill (APLOLAZA et al., 2005; ISABEL et al., 2001) and Eucalyptus grandis Hill ex Maiden (Retief and Stanger, 2009). These BD value are also higher than commercial used hybrid eucalypt clones which ranged from 0.404 to $0.427 \mathrm{~g} \mathrm{~cm}^{-3}$ sampled at age 51 months in southern China (Wu et al., 2011b). Meanwhile, the mean $\mathrm{BD}$ value is accord with the range of basic density for pulpwood in eucalypts that has been suggested as 0.47 to $0.55 \mathrm{~g} \mathrm{~cm}^{-3}$ and pulp yield decrease sharply when basic density falls below 0.4 or exceeds 0.60 (IKEMORI et al., 1986; DEAN. 1995; KIEN et al., 2008). Thus, some of these assessed clones would likely substantial improve pulp production in China and some of them need to be simultaneously addressed in an efficient propagation and commercial use in China.

Growth stresses are involving in effecting end splitting of logs, deflection during sawing and deformation of boards as stresses are released during sawing operations (RAYMOND et al., 2004). It is well known that MOE can be used to estimate growth stresses without the need for harvesting trees. Our results showed that the MOE values ranged from 7.15 to $30.96 \mathrm{GPa}$ with 15.83 $( \pm 0.21) \mathrm{GPa}$ of mean value (Table 3$)$. Findings of the value of MOE were somewhat difference with previous studies, in which Eucalyptus cloeziana F. Muell showed the highest value (14.2 to $15.7 \mathrm{GPa}$ ), followed by Eucalyptus pilularis Smith (12.2 to $13.5 \mathrm{GPa})$ and Eucalyptus dunnii Maiden (10.7 to $12.6 \mathrm{GPa}$ ) (WARREN et al., 2009). These values are much higher than other species such as radiata pine (3.7 to $7.5 \mathrm{GPa}$ ) (CHAUHAN and WALKER, 2006; WAGHORN et al., 2007; MATHESON et al., 2008) and Japanese larch trees (7.35 to $15.39 \mathrm{GPa}$ ) (IsHIGURI et al., 2008). The possible reason of higher MOE value and range would be the bigger wood density and variation among clones implying great gain after selection.

Stem-branch characteristics and bark percentage considered as important traits for breeding have been widely used in tree improvement (WEI and BORRALHO, 1997; MAHMOOD et al., 2003; HAI et al., 2008, 2008b; KIEN et al., 2008). The mean value of STR and BRA were 1.46 $( \pm 0.01)$ and $1.73( \pm 0.01)$ (Table 3$)$ implying most of the clones had slight bend at one position with few knots and acceptable branch. The bark percentage ranged from $1.1 \%$ to $28.1 \%$ and the mean was $14.7 \%( \pm 0.00)$, higher than published material by WEI and BORRALHO (1997). RETIEF and StANGER (2009) found that the bark percentage was $7.43 \%$ for $E$. grandis, $17.31 \%$ for $E$. urophylla, $7.97 \%$ for $E$. grandis $\times E$. urophylla hybrids and $9.50 \%$ for $E$. urophylla $\times E$. grandis hybrids from control-pollinated families at 75 months in South African. The mean value of WW was $99.57( \pm 3.39) \mathrm{kg}$ and the maximum value was nearly twenty times than minimum, expressing great variation among clones. However, the individual tree wood weight which are strongly related to end production and economically important in pulp production has not been studied extensively.

The coefficient of variation and repeatability of all traits at three ages are given in Table 3. Coefficients of variation ranged from $12.12 \%$ to $53.16 \%$ for growth traits, $9.02 \%$ to $20.18 \%$ for wood properties, $21.75 \%$ to $22.71 \%$ for stem-branch characteristics, $28.31 \%$ for bark percentage and $51.20 \%$ for individual tree wood weight. These were in agreement with the variability observed in previous studies by WEI and BORRALHO (1997), in which coefficients of variation for wood properties and bark percentage ranged from $7.9 \%$ to $13.6 \%$ and from $29.1 \%$ to $29.9 \%$ for $E$. urophylla in south east China. KIEN et al. (2010) reported that the coefficients of variation were less than $10 \%$ for wood properties and between $10 \%$ and $20 \%$ for growth traits. These results also showed that basic density had least variation, stembranch characteristics and bark percentage were moderate and volume both under bark and over bark always had greatest variation, indicating that the scope for selection among clones would be considerable. This conclusion was consistent with previous studies in Acacia auriculiformis A. Cunn. Ex Benth. (HAI et al., 2008) and Eucalyptus (KIEN et al., 2008, 2010). Furthermore, the coefficient of variation for growth traits generally increased with age trend and it reached peak in $53.16 \%$ at 96 months. The individual tree wood weight also had bigger variation among clones probably due to the affects by volume under bark.

Estimates of repeatability for growth traits at clone mean level ranged from 0.36 at 21 age months to 0.53 at 52 month old. At ages 52 and 71 months, the clonal repeatabilities for growth traits in this study were moderate to high ( 0.40 to 0.53$)$, suggesting that considerable selection responses could be expected for growth following selection and subsequent propagation of the selected clones for planting. XIANG et al. (2003) found that the heritabilities increased over time from a total of 275 parents and 690 full-sib families from 23 diallel tests of loblolly pine (Pinus taeda L.) through age 8 in the Northern, Coastal and Piedmont test region of the southeastern U.S.. In general, the difference of repeatabilities between growth and wood traits was not as much as earlier published results (KUBE et al., 2001; PliURA et al., 2007; STACKPOLE et al., 2010). Furthermore, the repeatabilities of growth and wood traits were always higher than other traits. The high repeatability estimates for wood density were consistent with earlier results (LIMA et al., 2000; MUNERI and RAYMOND, 2000). GREAVES et al. (1996) observed that repeatability of ring density averaged 0.37 in $E$. nitens at 7-year-old. Repeatabilities of stem-branch characteristics were 
Table 4. - Genotypic (below diagonal) and phenotypic correlations (above diagonal) among 21, 52, 71 and 96 months.

\begin{tabular}{|c|c|c|c|c|c|c|c|c|c|c|c|c|c|c|c|c|c|c|c|c|}
\hline \multirow[b]{2}{*}{ Age } & \multirow[b]{2}{*}{ Traits } & \multicolumn{3}{|c|}{21 months old } & \multicolumn{3}{|c|}{52 months old } & \multicolumn{3}{|c|}{71 months old } & \multicolumn{10}{|c|}{96 months old } \\
\hline & & HGT & DBHOB & VOL & HGT & DBHOB & $\mathrm{VOL}$ & HGT & DBHOB & VOL & HGT & DBHOB & VOL & STR & BRA & $\begin{array}{l}\text { Bark } \\
\text { Perc }\end{array}$ & SWV & $\mathrm{BD}$ & MOE & WW \\
\hline \multirow{3}{*}{$\begin{array}{l}21 \text { months } \\
\text { old }\end{array}$} & HGT & & $0.71^{\prime \prime}$ & $0.83^{\prime \prime}$ & $0.30^{\circ}$ & $0.48^{\circ}$ & $0.40^{\prime \prime}$ & $0.41^{\circ}$ & $0.36^{\circ}$ & $0.38^{\circ}$ & $0.38^{\circ \prime}$ & $0.38^{\prime \prime}$ & $0.36^{\prime \prime}$ & $-0.28^{\circ}$ & $-0.28^{\circ}$ & -0.06 & -0.03 & 0.04 & -0.01 & $0.48^{\circ}$ \\
\hline & DBHOB & 0.58 & & $0.95^{\circ}$ & $0.48^{\prime \prime}$ & $0.76^{\circ}$ & $0.68^{\circ}$ & $0.51^{*}$ & $0.54^{\prime .}$ & $0.55^{\circ}$ & $0.55^{\circ}$ & $0.65^{\prime \prime}$ & $0.63^{\circ}$ & -0.14 & $-0.27^{\star}$ & -0.07 & -0.03 & 0.06 & -0.07 & $0.69^{\circ}$ \\
\hline & VOL & 0.79 & 0.91 & & $0.41^{\circ}$ & $0.72^{*}$ & $0.64^{\circ}$ & $0.50^{\circ}$ & $0.53^{\circ}$ & $0.54^{\circ}$ & $0.52^{\circ}$ & $0.60^{\circ}$ & $0.60^{\circ}$ & -0.16 & $-0.30^{\circ}$ & -0.07 & -0.03 & 0.05 & -0.05 & $0.73^{\circ}$ \\
\hline \multirow{3}{*}{$\begin{array}{l}52 \text { months } \\
\text { old }\end{array}$} & HGT & 0.61 & 1.03 & 0.98 & & $0.66^{\circ}$ & $0.82^{\circ}$ & $0.87^{\circ}$ & $0.49^{\prime \prime}$ & $0.60^{\circ}$ & $0.84^{\circ}$ & $0.54^{\circ}$ & $0.62^{\prime \prime}$ & -0.23 & $-0.35^{\prime \prime}$ & -0.08 & -0.04 & 0.07 & 0.00 & $0.64^{\circ}$ \\
\hline & DBHOB & 0.71 & 0.78 & 1.07 & 1.06 & & $0.94^{\circ}$ & $0.60^{\circ}$ & $0.75^{\circ}$ & $0.75^{\circ}$ & $0.80^{\circ}$ & $0.84^{\circ}$ & $0.83^{\circ}$ & -0.19 & $-0.35^{\circ}$ & -0.04 & -0.02 & 0.03 & -0.03 & $0.81^{\circ}$ \\
\hline & VOL & 0.67 & 1.10 & 0.93 & 0.89 & 0.71 & & $0.70^{\circ}$ & $0.72^{\prime \prime}$ & $0.78^{\circ}$ & $0.88^{\circ}$ & $0.82^{\prime \prime}$ & $0.87^{\prime \prime}$ & -0.20 & $-0.36^{\prime \prime}$ & -0.06 & -0.01 & 0.04 & -0.02 & $0.84^{\circ}$ \\
\hline \multirow{7}{*}{$\begin{array}{l}71 \text { months } \\
\text { old }\end{array}$} & HGT & 0.85 & 1.06 & 0.38 & 0.95 & 0.94 & 0.87 & & $0.50^{\circ}$ & $0.65^{\circ}$ & $0.78^{\circ}$ & $0.57^{\circ}$ & $0.59^{\circ}$ & $-0.32^{\circ}$ & $-0.32^{\prime \prime}$ & -0.09 & -0.06 & 0.09 & 0.04 & $0.59^{\circ}$ \\
\hline & DBHOB & 0.52 & 0.71 & 0.38 & 0.88 & 1.08 & 1.08 & 0.73 & & $0.97^{\circ}$ & $0.64^{\circ}$ & $0.64^{\prime \prime}$ & $0.67^{\circ}$ & -0.18 & $-0.25^{\circ}$ & -0.05 & -0.02 & 0.06 & 0.04 & $0.68^{\circ}$ \\
\hline & VOL & 0.63 & 0.85 & 0.58 & 1.05 & 1.08 & 1.07 & 0.85 & 0.94 & & $0.72^{\circ}$ & $0.66^{\circ}$ & $0.71^{\prime}$ & -0.20 & $-0.26^{\circ}$ & -0.04 & -0.03 & 0.06 & 0.04 & $0.72^{\circ}$ \\
\hline & HGT & -0.32 & -0.21 & 0.58 & 0.46 & 0.72 & 0.83 & 0.74 & 0.48 & 0.37 & & $0.78^{\circ}$ & $0.85^{\circ}$ & -0.22 & $-0.41^{\circ}$ & -0.10 & -0.10 & 0.07 & -0.09 & $0.83^{\circ}$ \\
\hline & DBHOB & -0.18 & 0.12 & -0.32 & 0.23 & 0.27 & 0.37 & 1.05 & 0.72 & 0.55 & 0.97 & & $0.96^{\prime \prime}$ & -0.14 & $-0.31^{\prime \prime}$ & -0.08 & -0.04 & 0.05 & -0.06 & $0.93^{\circ}$ \\
\hline & VOL & -0.90 & -0.81 & -1.16 & 0.00 & 0.16 & 0.41 & 0.89 & 0.31 & 0.70 & 0.98 & 1.00 & & -0.13 & $-0.33^{\prime}$ & -0.08 & -0.07 & 0.05 & -0.09 & $0.97^{\circ}$ \\
\hline & STR & -0.83 & -0.74 & -0.90 & -0.83 & -0.79 & -0.55 & -0.92 & -1.27 & -1.38 & -1.08 & -0.51 & -0.65 & & 0.15 & 0.04 & 0.02 & -0.05 & -0.05 & -0.20 \\
\hline 96 months & BRA & -1.09 & 0.07 & -0.73 & -0.61 & -0.55 & -0.78 & -1.01 & -0.82 & -1.35 & -0.05 & -0.26 & 0.14 & 0.13 & & $0.28^{\circ}$ & 0.18 & -0.22 & 0.15 & $-0.36^{\prime \prime}$ \\
\hline \multirow[t]{5}{*}{ old } & Bark Perc & -1.33 & -0.19 & -1.21 & -0.76 & -0.65 & -0.94 & -0.98 & -0.71 & -1.11 & -0.38 & -0.60 & -0.34 & -1.58 & 0.22 & & -0.04 & $-0.95^{\circ}$ & -0.18 & -0.12 \\
\hline & swv & -1.28 & -0.24 & -0.16 & -1.19 & -0.73 & -1.18 & -0.73 & -0.97 & -1.04 & -0.48 & -0.86 & -0.51 & -1.17 & -0.40 & -0.61 & & 0.24 & $0.43^{\circ}$ & 0.01 \\
\hline & $\mathrm{BD}$ & -0.55 & -0.22 & -0.78 & -0.21 & -0.14 & -0.44 & -0.12 & 0.28 & -0.03 & 0.01 & 0.14 & 0.20 & -0.45 & -0.57 & -1.01 & 0.13 & & 0.24 & 0.10 \\
\hline & MOE & -1.32 & -0.04 & -1.05 & -0.72 & -0.38 & -0.83 & -0.27 & -0.35 & -0.73 & -0.32 & -0.17 & -0.05 & -0.49 & -0.11 & -0.59 & 0.07 & 0.60 & & 0.10 \\
\hline & WW & -0.74 & 0.48 & -0.22 & 0.01 & 0.38 & 0.24 & 1.19 & 1.13 & 0.92 & 0.57 & 0.54 & 0.74 & -0.97 & -0.23 & -0.33 & 0.21 & 0.53 & 0.30 & \\
\hline
\end{tabular}

HGT height; DBHOB diameter at breast height over bark; VOL volume over bark; STR stem straightness; BRA branch size; Bark Perc bark percentage; SWV stress wave velocity; BD wood basic density; MOE modulus of elasticity; WW individual tree wood weight. $*, * *$ means significant differences at $5 \%$ and $1 \%$ level respectively.

ranged from 0.21 to 0.24 which lower that of the individual tree wood weigh. Among the traits studied, the repeatability of bark percentage was very much lower than for other traits. SWV and MOE relatively had higher repeatabilities than other traits, agreeing with earlier results by Wu et al. (2011b). These results support that sawn wood defects related traits like log end splitting, board end splitting and cupping are very heritable and selection of trees based on them brings enormous genetic gain (GARCIA, 2002).

\section{Genotypic and phenotypic correlations between traits among ages}

Genotypic and phenotypic correlations among traits at three ages are listed in Table 4 . There were some genotypic correlations among studied traits above 1.00 , probably due to imprecise estimation and may therefore be unreliable. Since volume was calculated from measurements of diameter taken along the stem of each tree, positive correlations some degree of always exited among DBHOB, HGT and volume whether in Eucalyptus, Populus or other species (GREAVEs et al., 1997; HANSEN and Roulund, 1996; Kumar and SingH, 2001; HAI et al., 2008; KIEN et al., 2010). In this study, DBHOB and HGT had strongly positive genotypic and phenotypic correlations with VOL, ranging from 0.65 to 1.00. Generally speaking, the genotypic correlations among DBHOB, HGT and VOL at same age increased with age trends but no significant trends on phenotypic correlations. The correlations between DBHOB and VOL, however, were generally higher than for those between HGT and VOL, indicating the importance of DBHOB in selecting for improved stem volume (WU et al., 2011b). Age-age genetic correlations of early
DBHOB, HGT and VOL with 96-months same traits increased over time. XIANG et al. (2003) reported that age-age genetic correlations of early height with 8-year volume increased significantly in the first 3-4 years, and then leveled off after that in loblolly pine. The genotypic correlations between VOL at 21 and 96 months ranged from -0.81 to -1.16 indicating that selection on growth traits at 21 months can not be effective to predict growth traits at 96 months whereas it could be used to predict growth traits at 52 and 71 months. Published material (GREAVES et al., 1997; OsORIO et al., 2003; KIEN et al., 2008) summarized that early selection age for eucalypts should be at least 3 years old.

Stem straightness and branch size generally had negative genotypic and phenotypic correlations with growth traits and basic density, agreeing with early published material (MAHMOOD et al., 2003). However, KIEN et al. (2009) found that genetic correlations between growth and stem traits were low to moderate in two open-pollinated progeny trials of Eucalyptus urophylla at two sites in northern Vietnam. The genotypic and phenotypic correlations between stem straightness and branch size were 0.13 and 0.15 respectively. The genotypic and phenotypic correlations between bark percentage and other studied traits except for stem straightness and branch size were generally negative, indicating that growth traits and bark percentage were not independent. Wei et al. (1997) and RETIEF et al. (2009) also observed negative genotypic correlations between bark percentage and growth traits whereas the correlations between bark percentage and basic density were positive. This provides less possibility to reduce bark proportion and simultaneously improve growth traits and wood properties. 
Weakly to strongly negatively genotypic correlations and weakly negatively phenotypic correlations were found between SWV and growth traits. Actually, BD and SWV are not totally independent of each other. SWV was found to be weakly positively correlated with BD ( $\mathrm{r}$ $=0.13$ and 0.24 ), indicating that the average basic density can be improved by selecting for improved SWV (WANG et al., 2000; CHAUHAN and WALKER, 2006; Wu et al., 2011a). CHAUHAN and WALKER (2006) reported a low correlation between SWV and outerwood density for young trees of Pinus radiata, but it increased with time and was significant at 25 years. The genotypic correlations between growth traits and $\mathrm{BD}$ were ranged from -0.78 to 0.28 whereas weakly positive phenotypic correlations were found between growth traits and BD, ranging from 0.03 to 0.09 . Interestingly, the genotypic correlations between growth traits and $\mathrm{BD}$ tended to be increased from negative to positive with age trends, implying that multiple selection gain can be got from both growth traits and $\mathrm{BD}$ at elder age. The genotypic and phenotypic correlations between growth traits and MOE were generally from strongly negative to slightly positive. Growth traits and wood properties generally had positive genotypic and phenotypic correlations with WW. Nevertheless, slightly and strongly negative genotypic and phenotypic correlations between WW and stem-branch characteristics and bark percentage have been found in this study.

\section{Genetic gain for different purposes with different traits by age trend}

The simple weighting coefficient method depending on different selection purposes gives different weight to different traits and then calculates selection index value for different clones or families. According to the measured traits, VOL at 96 age months, STR, BRA, Bark Perc, BD and MOE were assumed with 0.4, 0.1, $0.1,-0.1,0.3$ and 0.2 for large timber respectively. The

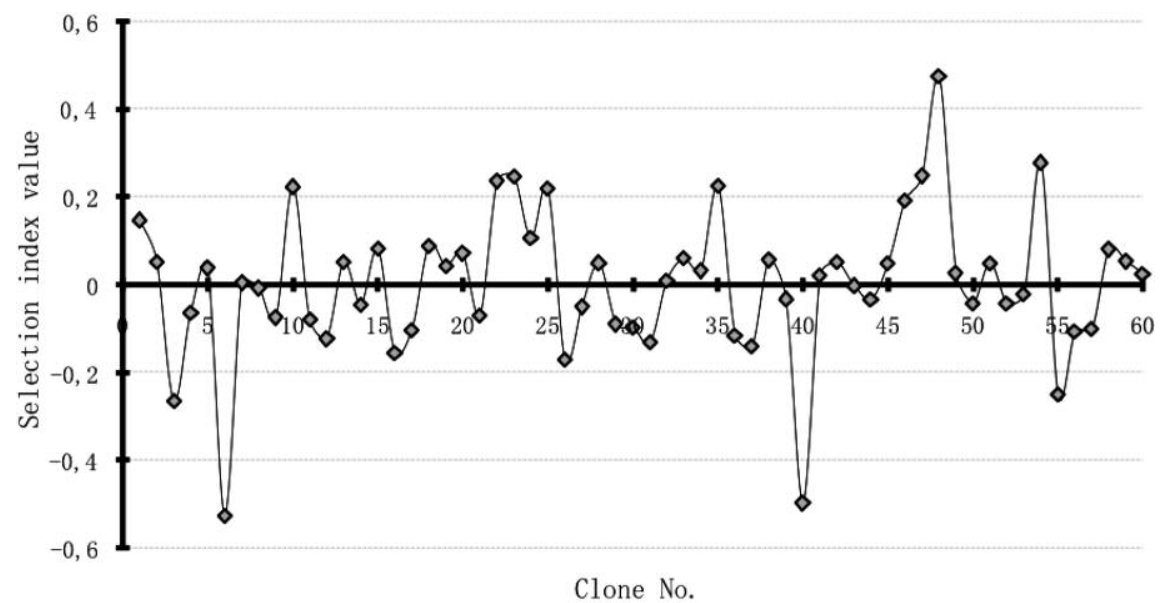

Figure 1. - Selection index values of clones assessed by simple weighting coefficient equation.

Table 5. - Mean and genetic gains of six selected clones.

\begin{tabular}{ccccccc}
\hline Clone & VOL $\left(\mathrm{m}^{3}\right)$ & STR & BRA & Bark Perc $(\%)$ & MOE $(\mathrm{GPa})$ & $\mathrm{BD}\left(\mathrm{g} \mathrm{cm}^{-3}\right)$ \\
\hline 48 & $0.215(0.04)$ & $1.00(0.00)$ & $2.00(0.33)$ & $15.44(0.00)$ & $15.06(0.08)$ & $0.63(0.03)$ \\
54 & $0.334(0.04)$ & $1.38(0.12)$ & $2.00(0.18)$ & $13.48(0.01)$ & $18.24(0.77)$ & $0.51(0.01)$ \\
47 & $0.233(0.02)$ & $1.33(0.12)$ & $2.17(0.24)$ & $12.29(0.01)$ & $19.57(1.10)$ & $0.53(0.01)$ \\
23 & $0.101(0.01)$ & $1.67(0.14)$ & $2.33(0.14)$ & $11.39(0.00)$ & $22.16(0.72)$ & $0.56(0.00)$ \\
22 & $0.333(0.03)$ & $1.18(0.10)$ & $1.27(0.15)$ & $12.58(0.00)$ & $17.99(0.64)$ & $0.52(0.01)$ \\
35 & $0.336(0.04)$ & $1.33(0.14)$ & $1.67(0.27)$ & $9.45(0.00)$ & $14.36(0.08)$ & $0.52(0.01)$ \\
Selected mean & $0.259(0.04)$ & $2.68(0.11)$ & $1.91(0.20)$ & $12.44(0.01)$ & $17.90(0.86)$ & $0.54(0.01)$ \\
General mean & $0.227(0.01)$ & $2.54(0.01)$ & $1.73(0.01)$ & $14.65(0.00)$ & $15.83(0.21)$ & $0.50(0.00)$ \\
Genetic gain $(\%)$ & 6.60 & 1.16 & 2.45 & -1.06 & 4.57 & 4.93 \\
\hline
\end{tabular}

VOL volume over bark; STR Stem straightness; BRA branch size; Bark Perc bark percentage; MOE modulus of elasticity; BD wood basic density; The Selected mean and General mean are the means of the selected clones, and the means of all data. 


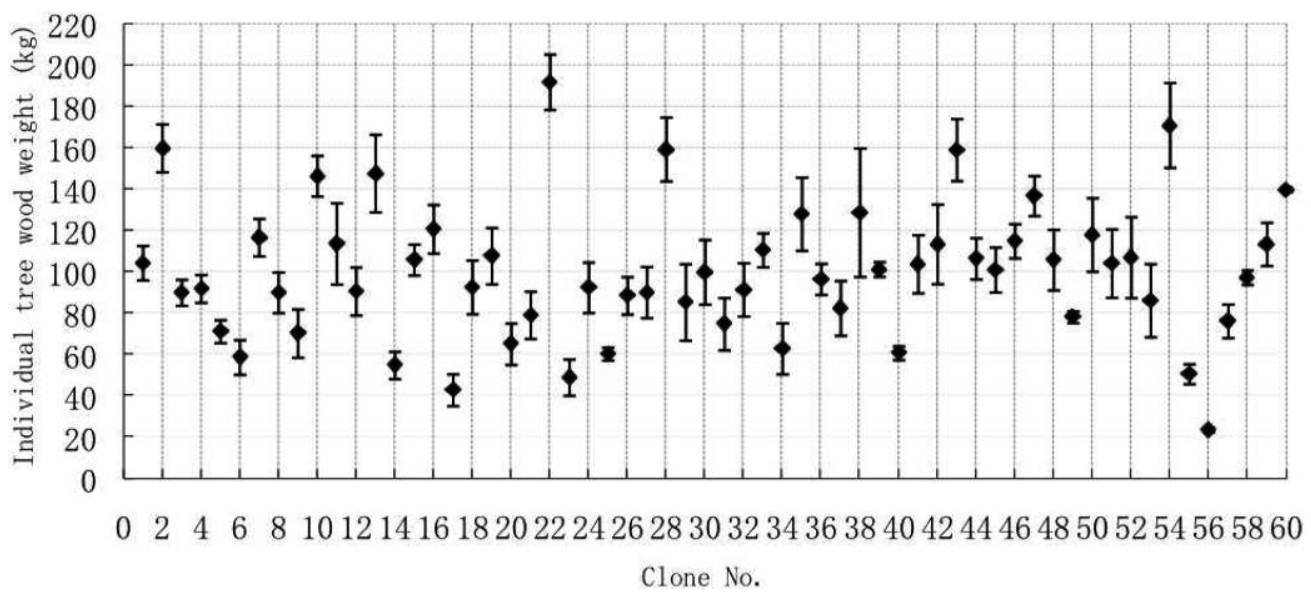

Figure 2. - Mean values ( \pm SE) of WW (individual tree wood weight) of clones at 96 age months.

selection index values of clones are given in Figure 1. The clonal selection index values ranged from -0.5 to 0.47 which somewhat smaller than published results (XU et al., 2009), implying smaller variation among clones. XU et al. (2009) found that the selection index values ranged from -1.72 to 0.62 on Eucalyptus hybrids at four years old. The mean and genetic gains of six selected clones by $10 \%$ selection proportion are presented in Table 5. Clone 48, 54, 47, 23, 22 and 35 were selected with higher selection index value. However, it was interesting to find that the six clones were all from different provenance showing good families can be found within all provenances. Therefore, the breeding population should in corporate families from several provenances to maintain and improve genetic gain and diversity in the breeding program (KIEN et al., 2009). The genetic gain ranged from -1.06 to 6.60 indicating that clones with higher growth, basic density and MOE always had thin bark percentage, smaller branch size and slight bend on stem.

Tree breeding is, after all, a combination of activities aiming to improve the performance of purpose plants under a given forest management system (BORRALHO, 2002). In most cases, such system major in eucalypts plantation always managed to provide wood-chips, or wood to supply directly a mill for pulp in China. The individual tree wood weight, calculated based on growth traits and wood basic density should be recognized as a direct indicator for wood-chips or pulp production. The mean values of WW of clones at 96 age months and direct responses for different selection proportions for WW are given in Figure 2 and Figure 3. The mean values of $\mathrm{WW}( \pm \mathrm{SE})$ ranged from 23.41 to $191.63 \mathrm{~kg}$ at clonal level, and most of them were in the range of 40 to $160 \mathrm{~kg}$. Clone 22, Clone 54, Clone 2, Clone 28, Clone 43 had higher WW, ranging from 158.86 to $191.63 \mathrm{~kg}$ whereas Clone 56, Clone 17, Clone 23, Clone 55, Clone 14 were the slowest growing. Clone 38 , Clone 54, Clone 11 , Clone 52, Clone 42 had higher variation, however Clone 56, Clone 60, Clone 49, Clone 25, Clone 40 grow steady in this site. The selection gain decreased sharply from $10 \%$ selection proportion to $30 \%$ selection proportion, and then reduced steady to $90 \%$ selection proportion. This result indicated that the selection proportion should be made no more than $30 \%$. Meanwhile, genetic diversity, time and costs also should be considered because the maintenance of them is an important issue in both forest conservation and tree breeding (DANUSEVICIUS and LINDGREN, 2002; JONES et al., 2006).

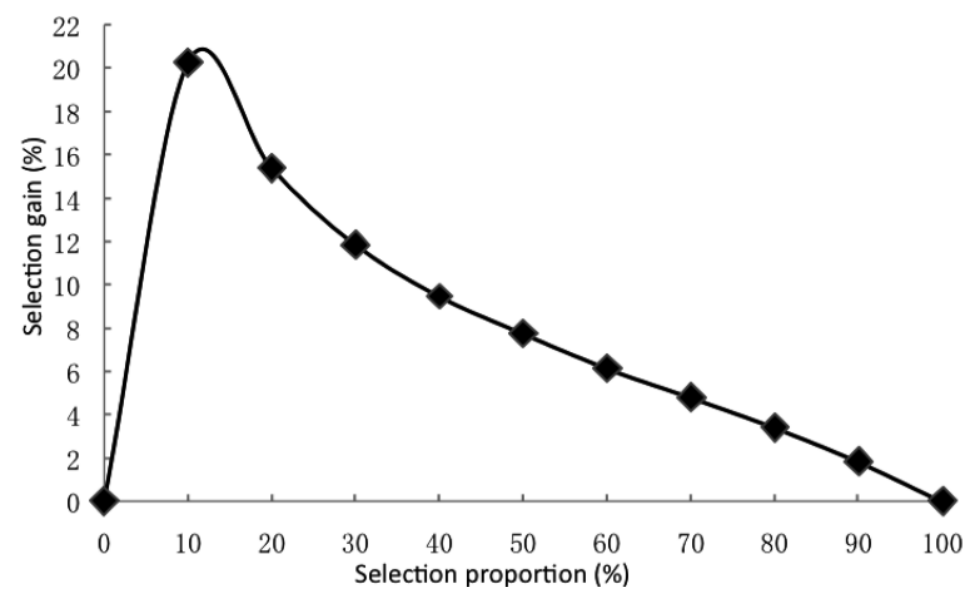

Figure 3. - Direct responses for different selection proportions when selecting for WW (individual tree wood weight). 


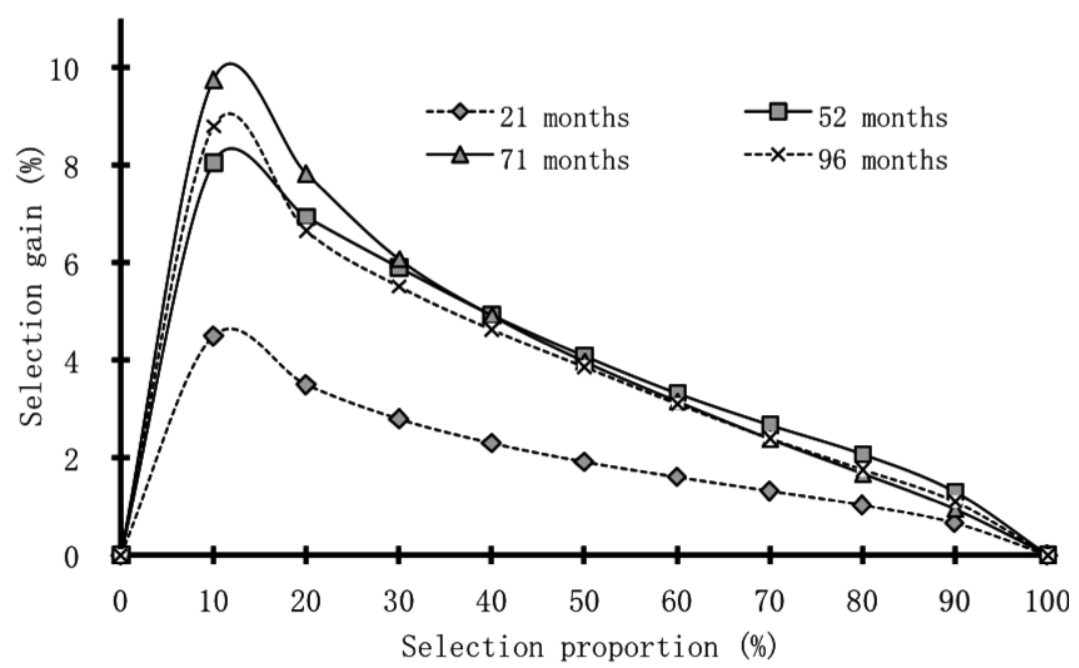

Figure 4. - Direct responses for different selection proportions when selecting for DBHOB (diameter at breast height over bark) at 21, 52, 71 and 96 months old.

The selection gain on DBHOB by different selection proportions at 21, 52, 71 and 96 months old are given in Figure 4. The selection gain at 21 months was always lower than that at other ages by any selection proportion. Generally, selection gain at 71 months was somewhat higher than that at other ages during $10 \%$ to $30 \%$ selection proportion. These results expressed that selection should be carried out at 71 months by no more than $30 \%$ selection proportion. These results indicated that maximum selection efficiency could be expected nearly 71 months, in agreement with the earlier findings by repeatability. KIEN et al. (2009) reported that efficiency of early selection at identical selection intensity generally increased to a maximum between age 2 and 4 years in $E$. urophylla in northern Vietnam (KIEN et al., 2009). Just like the selection gain trend of WW, these trends also decreased deeply from $10 \%$ selection proportion to $20 \%$ selection proportion, and then reduced steady to $90 \%$ selection proportion. Meantime, the selection gain reached similar value by range of $30 \%$ to $60 \%$ selection proportion at 52, 71 and 96 months, whereas the selection gain declined to similar value at any ages.

\section{Major conclusions and implications for breeding programs}

In the present study, the genotypic parameters of the studied traits and relationships between growth traits, wood properties, stem-branch characteristics and bark percentage were examined. In addition, the genetic gain for different purposes with different traits by age trend and implications for breeding programs were discussed.

Joint analysis of clonal trial in the present study showed five implications for tree improvement in $E$. urophylla in China. Primarily, the individual tree wood weight which had moderate clonal repeatability and high coefficient of variation in this study should been studied extensively for tree breeding, especially for pulp wood breeding. Secondly, the strongly negative genotypic correlations between volume over bark at 21 and 96 months implying that selection on growth traits at 21 months can not be effective to predict growth traits at 96 months whereas it could be used to predict growth traits at 52 and 71 months. Therefore more care should be taken regarding early selection age and prediction age. Thirdly, wood properties had similar coefficient of variation and repeatability as growth traits which is the primary trait used in most tree breeding programs indicating that tree breeding programs for wood properties can be as efficient as for growth. The genotypic correlations between growth traits and basic density tended to be increased from negative to positive with age trends, implying that selection for faster growth may not diminish basic density if it was measured at elder age. Fourthly, the six selected clones by simple weighting coefficient method were all from different provenance suggesting that good families can be found within all provenances and the breeding population should in corporate families from several provenances to maintain and improve genetic gain and diversity in the breeding program. Furthermore, the selection gain on diameter at breast height over bark by different selection proportions and estimates of repeatability for growth traits at clone mean level at 21, 52, 71 and 96 months old suggested that considerable selection responses could be expected for growth following selection and subsequent propagation of the selected clones for planting at ages 52 and 71 months.

\section{Acknowledgments}

The authors gratefully thank Prof. K. HARDING and R. E. PEGG for their earlier passional help to improve our writing ability, Dr. SimING GAN and Dr. JIE ZENG for their suggestions and helps and HongJian HuANG and PEITAO TAN from Xinhui Research Institute of Forestry Science for their painstaking assistance in sample preparation. Comments from anonymous reviewers are also appreciated. 


\section{References}

ApiolazA, L. A., C. A. Raymond and B. J. Yeo (2004): Genetic variation of physical and chemical wood properties of Eucalyptus globulus. Silvae Genetica 54(4-5): 160-164.

Aravanopoulos, F. A., K. H. Kim and L. Zsuffa (1999): Genetic diversity of superior salix clones selected for intensive forestry plantations. Biomass \& Bioenergy 16: 249-255.

Bernardo, A. L., M. G. F. Reis, G. G. Reis, R. B. Harrison and D. J. Firme (1998): Effect of spacing on growth and biomass distribution in Eucalyptus camaldulensis, $E$. pellita and E. urophylla plantations in southeastern Brazil. Forest Ecology and Management 104: 1-13-

Borralho, N. M. G. (2002): The challenges and lessons from breeding Eucalyptus. pp. 79-89. In: WEI, R., XU, D. Eucalyptus Plantation Research, Management and Development. Proceedings of the International Symposium held in Guangzhou, People's Republic of China. 1-6 September 2002 World Scientific Publishing Co. Pte. Ltd.

Bouvet, J. M., P. H. Vigneron and A. SAYA (2003): Trends in variance and heritabilities with age for growth traits in Eucalyptus spacing experiments. Silva Genetica 52(3-4): 121-133.

Bueren, M.V. (2004): Eucalypt tree improvement in China. Australian Centre for International Agricultural Research, Impact Assessment Series Report No. 30.

Bull, G. Q., M. Bazett, O. Schwab, S. Nilsson, A. White and S. MAGNINNIS (2006): Industrial forest plantation subsidies: impacts and implications. Forest Policy and Economics 9: 13-31.

Chauhan, S. S. and J. C. F. WALKer (2006): Variation in acoustic and density with age, and their interrelationships in radiation pine. Forest Ecology and Management 229: 388-394.

Chen, Y., L. KANG and B. DeLL (2006): Inoculation of Eucalyptus urophylla with spores of Scleroderma in a nursery in south China: comparision of field soil and potting mix. Forest Ecology and Management 222: 439-449.

DANUSEvicius, D. and D. LindGREN (2002): Clonal testing may be the approach to long-term breeding of Eucalyptus. In: R. P. WEI and D. P. XU (eds), Eucalyptus Plantation Research, Management and Development. World Scientific Publishing Co. Pte. Ltd. pp: 192-209.

DEAN, G. H. (1995): Objectives for wood fibre quality and uniformity. In: PotTs, B. M., Borralho, N. M. G., REID, J. B., Cromer, R. N., Tibbits, W. N. and Raymond, C. A. (eds) Eucalyptus plantations: improving fibre yield and quality. CRC THF -IUFRO Conf., Hobart, 19-24 Feb. pp 483.

Dickson, R. L., C. A. RAYond, W. Joe and C. A. Wilkinson (2003): Segregation of Eucalyptus dunnii logs using acoustics. Forest Ecology and Management 179: 243-251.

FANG, S., X. XU, S. LU and L. TANG (1999): Growth dynamics and biomass production in short-rotation popar plantations: 6-year results for three clones at four spacings. Biomass \& Bioenergy 17: 415-425.

Forrester, D., J. Bauhus, A. L. Cowie and J. K. VANClay (2006): Mixed-species plantations of Eucalyptus with nitrogen-fixing trees: a review. Forest Ecology and Management 233: 211-230.

GAN, S., M. LI, F. LI, K. WU and J. BAI (2004): Genetic analysis of growth and susceptibility to bacterial wilt (Ralstonia solanacearum) in Eucalyptus by interspecific factorial crossing. Silva Genetic, 53(5-6): 254-258.
GARCIA, J. N. (2002): Gains and losses on sawn wood yield and quality through forest improvement, management and sawing strategies. In: R. WEI and D. XU (eds), Eucalyptus Plantation Research, Management and Development. World Scientific Publishing Co. Pte. Ltd. pp: 392-403.

Greaves, B. L., N. M. G. Borralho, C. A. Raymond and A. FARRINGTON (1996): Use of a Pilodyn for the indirect selection of basic density in Eucalyptus nitens. Canadian Journal of Forest Research 26(9): 1643-1650.

Greaves, B. L., N. M. G. Borralho, C. A. RAYMond, R. Evans and P. H. Whiteman (1997): Age-age correlations in, and relationships between basic density and growth in Eucalyptus nitens. Silva Genetica 46(5): 264-270.

Hai, P. H., G. Jansson, C. Harwood, B. Hannrup and H. H. THINH (2008): Genetic variation in growth, stem straightness and branch thickness in clonal trials of Acacia auriculiformis at three contrasting sites in Vietnam. Forest Ecology and Management 255: 156-167.

HANSEN, J. K. and H. Roulund (1996): Genetic parameters for spiral grain, stem form, Pilodyn and growth in 13 year old clones of Sitka Spruce (Picea sitchensis (Bong.) Carr.). Silvae Genetica 46(2-3): 107-113.

Hardy, G. E., T. Burgess and B. Dell (2002): Potential threats of plant pathogens to Eucalyptus plantation in China. pp. 358-366. In: WEI, R., XU, D. Eucalyptus Plantation Research, Management and Development. Proceedings of the International Symposium held in Guangzhou, People's Republic of China. 1-6 September 2002 World Scientific Publishing Co. Pte. Ltd.

He, X., F. Li, M. Li, Q. Weng, J. Shi, X. Mo and S. GAN (2012): Quantitative genetics of cold hardiness and growth in Eucalyptus as estimated from $E$. urophylla $\times$ E. tereticornis hybrids. New Forests 43(3): 383-394.

HeNRI, D. C. J. (200): Soil-site productivity of Gmelina arborea, Eucalyptus urophylla and Eucalyptus grandis forest plantations in western Venezuela. Forest Ecology and Management 144: 255-264.

Huang LongBin and B. Dell (2002): Database system approach for integrated plantation nutrition management. In: R. P. WEI and D. P. XU (eds), Eucalyptus Plantation Research, Management and Development. World Scientific Publishing Co. Pte. Ltd. pp: 290-300.

Huang, S., W. Zhong, H. Huang, K. Huang, Q. Chen and X. LI (1999): Reseach on genetic variation and early selection of the provenances and open-pollinated families of Eucalyptus urophylla. Forest Research 12(4): 1-7 (in Chinese).

Ikemori, Y. K., F. C. G. Martins and B. J. Zobel (1986): The impact of accelerated breeding on wood Properties. In proceedings of the $18^{\text {th }}$ IUFRO World Conference Division 5: Forest products. Ljubljana, Yugoslavia. pp 358-368.

IsABel, M., M. H. AlmeidA and H. Pereira (2001): Provenance and site variation of wood density in Eucalyptus globulus Labill. at harvest age and its relation to a nondestructive early assessment. Forest Ecology and Management 144: 235-240.

IsIK, F. and B. LI (2003): Rapid assessment of wood density of live trees using the Resistograph for selection in tree improvement programs. Candida Journal of Forestry Research 33: 2426-2435.

Ishiguri, F., R. MAtsui, K. LizUka, S. Yokota and N. YoshizAWA (2008): Prediction of the mechanical properties of lumber by stress-wave velocity and Pilodyn penetration of 36-year-old Japanese larch trees. Holz Rooh Werkst 66: 275-280. 
Jones, T. H., D. A. Steane, R. C. Jones, D. Pilbeam, R. E. VAILlancourt and B. M. PotTs (2006): Effects of domestication on genetic diversity in Eucalyptus globulus. Forest Ecology and Management 234: 78-84.

Kien, N. D., G. Jansson, C. Harwood, C. Almqvist and H. T. HA (2008): Genetic variation in wood basic density and Pilodyn penetration and their relationships with growth, stem straightness and branch size for Eucalyptus urophylla S.T.Blake in Northern Vietnam. New Zealand Journal of Forestry Science 38(1): 160-175.

Kien, N. D., G. Jansson, C. HaRwood and H. H. Thinh (2009): Genetic control of growth and form in Eucalyptus urophylla in northern Vietnam. Journal of Tropical Forestry Science 21(1): 50-65.

Kien, N. D., G. Jansson, C. Harwood and C. Almqvist (2010): Clonal variation and genotype by environment interactions in growth and wood density in Eucalyptus camaldulensis at three contrasting sites in Vietnam. Silva Genetica 59(1): 17-28.

Knowles, L. R., L. W. Hansen, A. WendDing and G. DownEs (2004): Evaluation of non-destructive methods for assessing stiffness of Douglas fir trees. New Zealand Journal of Forestry Science 34(1): 87-101.

Kube, P. D., C. A. RAYMOND and P. W. BANHAM (2001): Genetic parameters for diameter, basic density, cellulose content and fibre properties for Eucalyptus Nitens. Forest Genetics 8(4): 285-294.

KumaR, D. and N. B. Singh (2001): Age-age correlation for early selection of clones of Populus in India. Silva Genetica 50(3-4): 103-108.

Kusnandar, D., N. W. Galwey, G. L. Hertzler and T. B. BUTCHER (1998): Age trends in variances and heritabilities for diameter and height in Maritime Pine (Pinus pinaster AIT.) in western Australia. Silva Genetica 47(2-3): 136-141.

Leite, S. M. M., C. A. Bonine, E. S. Mori, C. F. VAlle and C. L. NARINO (2002): Genetic variation in a breeding population of Eucalyptus urophylla S.T.Blake. Silva Genetica 51 (5-6): 253-256.

LEMENiH, M. and T. BeKELE (2004): Effect of age on calorific value and some mechanical properties of three Eucalyptus species grown in Ethiopia. Biomass \& Bioenergy 27: 223-232.

Li, F., S. Gan, Z. Zhang, Q. Weng, D. Xiang M. Li (2011): Microsatellite-based genotyping of the commercial Eucalyptus clones cultivated in China. Silvae Genetica 60(5): 216-223.

LI, G., J. XU, Z. LU, W. YANG, G. YANG and L. ZHONG (2005a): Studies on index selection of Eucalyptus urophylla families. Forest Research 18(1): 57-61 (in Chinese).

Li, G., J. Xu, Z. Lu, J. BAI and R. Chen (2005b): Selection and genetic analysis of families in second generation orchard of Eucalyptus urophylla. Journal of Nanjing Forestry University (Natural Science Edition) 29(6): 40-44 (in Chinese).

LIANG, K. and J. BAI (2003): Selection on growth and wind-resistance traits for provenances and families of Eucalyptus urophylla. Forest Research 16(6): 700-707 (in Chinese).

Lima, J. T., M. C. Breese and C. M. Cahalan (2000): Genotype-environment interaction in wood basic density of Eucalyptus clones. Wood Science and Technology 34: 197-206.

Lu, G., Z. Lu, J. Xu, R. ZhaO, Y. Li and G. Li (2003): Study on integrated selection and estimated the breeding value of Eucalyptus urophylla families progenies.
Guangdong Forest Science and Technology 19(4): 1-6 (in Chinese).

Lu, G., Z. Lu, J. Xu, R. Zhao, Y. Li and G. Li (2004): Study on growth variation of Eucalyptus urophylla clones. Guangxi Forestry Science 33(1): 42-45 (in Chinese).

LU, Z., J. XU, G. LI, J. BAI and S. QI (2004): The character analysis of Eucalyptus urophylla families progenies by open pollination. Journal of Central South Forestry University 24(5): 20-23 (in Chinese).

LU, Z., J. XU, G. LI, J. BAI, H. HuANG and Y. HU (2010): Study on multi-characters genetic analysis and selection index of 93 Eucalyptus urophylla clones. Eucalypt Science \& Technology 27(1): 1-8 (in Chinese).

Luo, J., G. Zhou, B. Wu, D. Chen, J. Cao, W. Lu, R. E. PEGG and R. J. ARNOLD (2010): Genetic variation and age-age correlations of Eucalyptus grandis at Dongmen Forest Farm in southern China. Australian Forestry 73(2): 69-82.

MacDonald, A. C., N. M. G. Borralho and B. M. Potts (1997): Genetic variation for growth and wood density in Eucalyptus globulus ssp. globulus in Tasmania (Australia). Silvae Genetica 46(4): 236-241.

McKenney, D. W., J. S. Davis and J. W. Turnbull (1991): The impact of Australian tree species research in China [A]. ACIAR Economic Assessment Series[C] Canberra. 12: $6-7$.

Mahmood, K., N. E. M. Marcar, M. H. Naqvi, R. J. ARnold, D. F. Crawford, S. IQbal and K. M. AKeN (2003): Genetic variation in Eucalyptus camaldulensis Dehnh. For growth and stem straightness in a provenance-family trial on saltland in Pakistan. Forest Ecology and Management 176: 405-416.

Matheson, A. C., W. J. Gapare, J. Ilic and H. X. Wu (2008): Inheritance and genetic gain in wood stiffness in Radiata pine assessed acoustically in young standing trees. Silva Genetica 57(2): 56-64.

McKenney, D. W. (1998): Australian tree species selection in China. Canberra, Canadian Forest Service Great Lakes Forestry Centre, ACIAR Projescts 8457 and 8848, Impact Assessment Series Report No. 8,

Miranda, I., M. H. AlmeidA and H. Pereira (2001): Provenance and site variation of wood density in Eucalyptus globulus Labill. at harvest age and its relation to a nondestructive early assessment. Forest Ecology and Management 149: 235-240,

Mo, X., S. Peng, T. Long, W. Chen and X. Yang (2002): Important traits and combined evaluation of eucalypt clones. pp. 102-108. In: WEI, R., XU, D. Eucalyptus Plantation Research, Management and Development. Proceedings of the International Symposium held in Guangzhou, People's Republic of China. 1-6 September 2002 World Scientific Publishing Co. Pte. Ltd.

Muneri, A. and C. A. RAYMOND (2000): Genetic parameters and genotype-by-environment interactions for basic density, Pilodyn and stem diameter in Eucalyptus globulus. Forest Genetics 7(4): 317-328.

Osorio, L. F., T. L. White and D. A. Huber (2001): Age trends of heritabilities and genotype-by-environment interactions for growth traits and wood density from clonal trials of Eucalyptus grandis Hill ex Maiden. Silva Genetica 50(1): 30-36.

Osorio, L. F., T. L. White and D. A. Huber (2003): Ageage and trait-trait correlations for Eucalyptus grandis Hill ex Maiden and their implications for optimal selection age and design of clonal trials. Theoretical Applied Genetics 106: 735-743. 
PeGG, R. E., H. J. LI, H. W. LI, G. F. ZHOU and D. Y. XIANG (2006): Study on artificial breeding of eucalypt hybrid in Guangxi. Guangxi Forestry Science 35(4): 238-242 (in Chinese).

Pelletier, M. C., M. Henson, S. Boyton, D. Thomas and J. VANCLAY (2008): Genetic variation in shrinkage properties of Eucalyptus pilularis assessed using increment cores and test blocks. New Zealand Journal of Forestry Science 38(1): 194-210.

Pliura, A., S. Y. Zhang, J. Mackay and J. Bousquet (2007): Genotypic variation in wood density and growth traits of poplar hybrids at four clonal trials. Forest Ecology and Management 238: 92-106.

QI, S. (2002): Eucalyptus in China. Beijing: China Forestry Publishing House. PP: 1-2 (in Chinese).

QuANG, T. H., N. D. KIEN, S. V. ARnOlD, G. JANsson, H. H. THINH and D. ClaPHAM (2009): Relationship of wood composition to growth traits of selected open-polinated families of Eucalyptus urophylla from a progeny trial in Vietnam. New Forests 39: 301-312.

Raymond, C. A., P. D. Kube, L. Pinkard, L. Savage and A. D. BRADLEY (2004): Evaluation of non-destructive methods of measuring growth stress in Eucalyptus globulus: relationships between strain, wood properties and stress. Forest Ecology and Management 190: 187-200.

Retief, E. C. L. and T. K. Stanger (2009): Genetic control of wood density and bark thickness, and their correlations with diameter, in pure and hybrid populations of Eucalyptus grandis and $E$. urophylla in south Africa. Southern Forests 71(2): 147-153.

StackPole, D. J., R. E. Vaillancourt, M. D. Aguigar and B. M. PotTs (2010): Age trends in genetic parameters for growth and wood density in Eucalyptus globulus. Tree Genetics ? Genomes 6: 179-193.

Toit, B. D., C. W. Smith, K. M. Little, G. Boreham and R. N. PALlETt (2010): Intensive, site-specific silviculture: manipulating resource availability at establishment for improved stand productivity. A review of Southern African research. Forest Ecology and Management 259: 1836-1845.

VARGhese, M., C. E. HaRwood, R. Hegde and N. Ravi (2008): Evaluation of provenances of Eucalyptus camaldulensis and clones of $E$. camaldulensis and $E$. tereticorni at contrasting sites in southern India. Silva Genetica 57(3): 136-141.

WAGHORN, M. J., M. S. WATT and E. G. MASON (2007): Influence of tree morphology, genetics, and initial stand density on outerwood modulus of elasticity of 17-yearold Pinus radiate. Forest Ecology and Management 244: 86-92.

Wang, H., D. C. Malcolm and A. M. Fletcher (1999): Pinus caribaea in China: introduction, genetic resources and future prospects. Forest Ecology and Management 117: $1-15$.

Wang, X., R. J. Ross, M. McClellan, R. J. Barbour, J. R. Erickson, J. W. Forsman and G. D. McGinnis (2000): Strength and stiffness assessment of standing trees using a nondestructive stress wave technique. Res. Pap. FPL-RP-585. U.S. Department of Agriculture, Forest Service, Forest Products Laboratory, Madison, WI. pp 197-206.

Warren, E., R. G. B. Smith, L. A. Apiolaza and J. C. F. WALKER (2009): Effects of stocking on juvenile wood stiffness for three Eucalyptus species. New Forests 37: 241-250.

WEI, R. (2002): Merging ecological concerns into sustainable management of short-rotation forest plantations in south china: practices by Sino-forest Corp. pp. 51-63. In: WEI, R., XU, D. Eucalyptus Plantation Research, Management and Development. Proceedings of the International Symposium held in Guangzhou, People's Republic of China. 1-6 September 2002 World Scientific Publishing Co. Pte. Ltd.

WeI, X. M. and N. M. G. BorRalHo (1996): A simple model to describe age trends in heritability in short rotation tree species. Tree Improvement for Sustainable Tropical Forestry. Proc. QFRI-IUFRO Conf., Caloundra, Queensland, Australia. pp: 178-181. [Refereed conference]

WEI, X. and N. M. G. BorRalHo (1997): Genetic control of basic density and bark thickness and their relationships with growth traits of Eucalyptus urophylla in south east China. Silvae Genetica 46(4): 245-250.

WRIGHT, J. A. and L. F. OsoRIO (1996): Comparison of Eucalyptus urophylla provenance performance at halfrotation in Colombia and hybrid strategies with Eucalyptus grandis. Forest Ecology and Management 83: 117-122.

Wu, S., J. Xu, G. LI, V. Risto, Z. Lu, B. Li and W. WANG (2010): Use of the Pilodyn for assessing wood properties in standing trees of Eucalyptus clones. Journal of Forestry Research 21(1): 68-72.

Wu, S., J. Xu, G. Li, V. Risto, Z. Lu, B. Li and W. WANG (2011a): Estimation of basic density and modulus of elasticity of eucalypts clones using nondestructive methods in southern China. Journal of Tropical Forestry Science 23(1): 51-56.

Wu, S., J. Xu, G. LI, Z. Du, Z. Lu, B. Li and W. WANG (2011b): Genotypic variation in wood properties and growth traits of Eucalyptus hybrid clones in southern China. New Forests 42: 35-50.

XIANG, B., B. LI and F. ISIK (2003): Time trend of genetic parameters in growth traits of pinus taeda L. Silvae Genetica 52(3-4): 114-121.

XU, D. and B. DELL (2002): Nutrient management of eucalypt plantations in south China. In: R. WeI and D. XU (eds), Eucalyptus Plantation Research, Management and Development. World Scientific Publishing Co. Pte. Ltd. pp: 269-288.

XU, J., J. BAI and Z. LU (2001): Some sustainable strategies of improvement and breeding for Eucalyptus tree species in southern China. Forest Research 14(6): 587-594 (in Chinese).

XU, J., Z. LU, G. LI and J. BAI (2003a): Study on integrated selection of provenances-families of Eucalyptus tereticornis. Forest Research 16(1): 1-7 (in Chinese).

XU, J., G. LI, Z. LU, J. BAI, G. LU and S. WANG (2003b): Progeny test for the open pollinated families of Eucalyptus urophylla in multiple sites. Forest Research 16(3): 277-283 (in Chinese).

XU, J., Z. LU, J. BAI, S. WANG, G. YANG and G. Li (2005): Genetic analysis and breeding value estimation of seedling seed orchard of Eucalyptus urophylla. Forest Research 18(5): 516-523 (in Chinese).

Xu, J., Z. Lu, G. Li, S. Wu, W. Wang, H. Huang, P. TaN and T. YE (2009): Study on the selection from clones of Eucalyptus hybrids. Eucalypt Science \& Technology 26(2): 1-8.

YANG, M. (2003): Present situation and prospects for eucalypt plantations in China. pp. 9-15. In: TURNBULL, J. W. Eucalypts in Asia Proceedings of an international conference held in Zhanjiang, Guangdong, People's Republic of China, 7-11 April 2003. Canberra, Australian Centre for International Agricultural Research Proceedings No. 111. 